\title{
ANALISIS KELIMPAHAN BAKTERI DI PERAIRAN BERMANGROVE DAN TIDAK BERMANGROVE DI PERAIRAN PANTAI UJUNG PIRING, JEPARA
}

\author{
Total Analysis Bacteria in Mangrove Water and Non-mangrove Water in the Coastal of Ujung Piring, Jepara
}

\section{Ilham Hauzan Mahrus, Niniek widyorini, Wiwiet Teguh Taufani}

\author{
Program Studi Manajemen Sumberdaya Perairan, Departemen Sumberdaya Akuatik \\ Fakultas Perikanan dan Ilmu Kelautan, Universitas Diponegoro \\ Jl. Prof. Soedarto, SH, Tembalang, Semarang, Jawa Tengah - 50275, Telp/Fax. +6224 7474698 \\ Email : ilham.mahrus9f@gmail.com
}

\begin{abstract}
ABSTRAK
Ekosistem mangrove merupakan salah satu ekosistem penting yang terdapat disepanjang garis pantai perairan tropis. Ekosistem mangrove memiliki peranan ekologi yang sangat penting, salah satunya yaitu tempat berlangsungnya proses dekomposisi. Bakteri sebagai dekomposer memiliki peran penting, sehingga kelimpahan bakteri pada perairan dapat dijadikan indikator kualitas lingkungan. Tujuan dari penelitian ini adalah untuk mengetahui kelimpahan bakteri, hubungannya dengan bahan organik dan mengetahui perbedaan total bakteri pada kawasan bermangrove dan tidak bermangrove. Penelitian ini dilaksanakan pada bulan April 2019 di perairan Pantai Ujung Piring, Jepara dan analisis total bakteri dilaksanakan di Laboratorium Manajemen Kesehatan Hewan Akuatik (MKHA), Balai Besar Perikanan Budidaya Air Payau Jepara. Pengambilan sampel menggunakan teknik purposive sampling. Penanaman bakteri dilakukan menggunakan metode spread plate. Perhitungan total bakteri menggunakan metode Total Plate Count (TPC). Analisis data menggunakan T-test dan Principal Component Analysis (PCA). Mangrove pada lokasi penelitian mayoritas jenis Rhizophora apiculata kemudian kelimpahan bakteri yang didapat pada kawasan bermangrove yaitu $2,5 \times 10^{3} \mathrm{CFU} / \mathrm{ml}$ sampai dengan $8,0 \times 10^{3} \mathrm{CFU} / \mathrm{ml}$. Sedangkan tidak bermangrove $1,4 \times 10^{3} \mathrm{CFU} / \mathrm{ml}$ sampai dengan 4,6 x $10^{3} \mathrm{CFU} / \mathrm{ml}$. Kesimpulan dari penelitian ini adalah nilai total bakteri termasuk kategori rendah, kemudian terdapat hubungan yang kuat antara total bakteri dengan bahan organik dan terdapat perbedaan nilai kelimpahan bakteri pada kawasan bermangrove dan tidak bermangrove.
\end{abstract}

Kata kunci: Total Bakteri; Mangrove; Bahan Organik; Total Plate Count; Principal Component Analysis

\begin{abstract}
Mangrove ecosystem is one of the important ecosystems along the tropical coastline. Mangrove ecosystems have a very important ecological role which is the place where decomposition takes place. Bacteria as decomposer have an important role, therefore total bacteria in the waters can be used as indicator of environmental quality. The purpose of this study was to determine the total bacteria, its relationship with organic matter and to know the difference in total bacteria in mangrove and non-mangrove areas. This research was conducted in April 2019 at Ujung Piring Beach, Jepara and a total bacterial analysis was carried out at the Laboratory of Aquatic Animal Health Management (MKHA), Brackishwater Aquaculture Center, Jepara. Sampling used purposive sampling method, bacterial planting used Spread Plate Method, total bacterial calculation used the Total Plate Count (TPC) method, data analysis used T-test and Principal Component Analysis (PCA). the majority of mangrove species are Rhizophora apiculata then total bacteria obtained in the mangrove area were $2.5 \times 10^{3}$ CFU/ml to $8.0 \times 10^{3} \mathrm{CFU} / \mathrm{ml}$. While in the non-mangrove area were $1.4 \times 10^{3} \mathrm{CFU} / \mathrm{ml}$ to $4.6 \times 10^{3} \mathrm{CFU} / \mathrm{ml}$. The conclusion is that the total bacterial value is in the low category, then there is a strong relationship between total bacteria and organic matter and there are differences in total bacteria among mangrove and nonmangrove area.
\end{abstract}

Keyword: Total Bacteria; Mangrove; Organic Matter; Total Plate Count; Principal Component Analysis

\section{PENDAHULUAN}

Ekosistem mangrove merupakan salah satu ekosistem penting yang terdapat disepanjang garis pantai perairan tropis. Ekosistem mangrove ini memiliki peranan ekologi yang sangat penting, salah satunya yaitu termpat berlangsungnya proses dekomposisi. Sehingga ekosistem mangrove ini merupakan daerah yang mempunyai produktifitas yang tinggi dan kaya akan unsur hara yang diperlukan oleh berbagai organisme. Secara ekologis hutan mangrove disamping sebagai habitat biota laut, juga merupakan tempat pemijahan ikan. Keragaman jenis mangrove dan keunikannya juga memiliki potensi sebagai tempat wisata dan juga sebagai perlindungan wilayah pesisir dan pantai, dari berbagai ancaman sedimentasi, abrasi, serta sebagai sumber pakan bagi berbagai biota (Zainuri et al., 2017)

\footnotetext{
${ }^{\circledR}$ Copyright by Management of Aquatic Resources (MAQUARES)
} 
Perairan pantai ujung piring merupakan kawasan pesisir yang terdapat area mangrove. Dalam ekosistem mangrove terdapat berbagai organisme yang berperan penting untuk menjaga keberlangsungan ekosistem tersebut. Salah satunya mikroorganisme yang mempunyai peran penting sebagai dekomposer dan juga berperan dalam siklus nitrogen. Keberadaan mikroorganisme pada ekosistem mangrove erat kaitannya dengan kestabilan ekosistem. Mikroorganisme berperan dalam siklus biogeokimia, serta terjadi simbiosis mutualisme antara bakteri dan tumbuhan (Dewi et al., 2017)

Bakteri mempunyai persebaran yang sangat luas, baik di tanah, air, dan sebagai simbiosis dari organisme lain. Salah satu tempat hidup dari bakteri yaitu pada ekosistem mangrove. Bakteri memiliki peranan penting terhadap ekosistem mangrove, salah satu peran bakteri pada ekosistem mangrove yaitu sebagai dekomposer dalam proses penguraian bahan organik. Ketersediaan bahan organik pada suatu perairan juga dapat mempengaruhi kelimpahan mikroorganime pada suatu perairan. Oleh sebab itu, kandungan total bakteri di sebuah perairan terutama sebagai penyedian unsur hara dapat digunakan sebagai indikator kesuburan perairan. (Marwan et al., 2015)

(Supriharyono, 2009) menyatakan bahwa kelimpahan bakteri pada perairan bermangrove dapat dipengaruhi oleh jenis mangrove yang terdapat pada kawasan tersebut. Kemudian bakteri juga mempunyai peran penting dalam siklus nitrogen, sehingga kelimpahan bakteri pada perairan juga dapat dipengaruhi oleh nitrat. Kelimpahan bakteri juga dapat dipengaruhi oleh beberapa faktor, salah satunya yaitu bahan organik. Bahan organik yang terdapat pada perairan Pantai Ujung Piring, Jepara berasal dari limbah rumah tangga, limbah tambak dan dari penguraian serasah daun mangrove. Sehingga total bakteri pada perairan Pantai Ujung Piring, Jepara diperkirakan mempunyai nilai yang berbeda-beda. Maka dari itu perlu dilakukan penelitian untuk mengetahui tentang total bakteri dan hubungannya dengan bahan organik pada perairan tersebut.

Tujuan dari penelitian ini adalah untuk mengetahui total bakteri, serta hubungannya dengan bahan organik dan untuk mengetahui perbedaan total bakteri pada kawasan bermangrove dan tidak bermangrove di perairan Pantai Ujung Piring, Jepara.

\section{MATERI DAN METODE PENELITIAN}

\section{A. Materi}

Materi yang digunakan dalam penelitian adalah air pada area bermangrove dan tidak bermangrove di perairan Pantai Ujung Piring, Jepara sesuai dengan titik pengambilan sampel yang telah ditentukan. Alat yang digunakan dalam penelitian adalah Petri dish, bunsen, tabung reaksi, mikro pipet, botol sampel, autoclave, alumunium foil, rak tabung reaksi, inkubator, mikroskop, magnetik stirer, timbangan, korek api, oven, termometer, $\mathrm{pH}$ paper, refraktometer, cool box, GPS, alat tulis, dan kamera.

\section{B. Metode}

Metode digunakan dalam penelitian ini adalah metode survei, metode ini adalah salah satu dalam metode penelitian yang digunakan untuk melihat keadaan suatu kawasan berdasar pada penelitian dan kajian secara faktual. Menurut Purnomo et al. (2016), bahwa metode survei merupakan metode penelitian yang dilakukan untuk mengetahui kondisi suatu ekosistem dan mencari keterangan dengan melakukan penelitian dan pendekatan kajian secara faktual.

\section{Pemilihan Lokasi Sampling}

Penentuan lokasi pengambilan sampel dilakukan menggunakan metode purposive sampling berdasarkan perairan bermangrove dan tidak bermangrove. Menurut Rizqiana et al. (2017) bahwa metode pengambilan sampel menggunakan metode purposive sampling yaitu pengambilan data dengan alasan dan pertimbangan tertentu dengan sengaja untuk mendapatkan sampel yang mewakili baik area maupun kelompok sampel sehingga didapat gambaran lokasi penelitian secara keseluruhan. Pengambilan sampel pada Pantai Ujung Piring dilakukan pada dua stasiun pengamatan. Stasiun satu merupakan daerah yang bermangrove dengan tiga titik sampling. Kemudian stasiun dua merupakan daerah yang tidak bermangrove dengan tiga titik sampling. Pengambilan sampel dilakukan sebanyak tiga kali pengulangan, dengan jarak waktu satu minggu tiap satu kali pengambilan sampel. Pengambilan sampel dilakukan pada tanggal 1 April, 8 April dan 15 April 2019.

\section{Pengambilan Sampel}

Pengambilan sampel air untuk keperluan analisis total bakteri dan bahan organik dengan menggunakan botol sampel. Pengambilan sampel air dilakukan dengan cara tutup botol sampel tersebut dibuka kemudian dimasukkan kedalam perairan hingga terisi air sampel, lalu menutup botol sampel yang telah terisi sampel. Setelah itu dimasukkan kedalam cool box untuk menjaga sempel tetap stabil. Pengambilan air sampel dilakukan pada setiap titik pada setiap stasiun yang memiliki jarak yang sama di setiap stasiun, dimana terdapat dua stasiun dengan tiga titik setiap stasiunnya. Menurut Nasution (2003) pengambilan sampel yang dilakukan dengan teknik purposive sampling didasarkan pada pertimbangan penelitinya saja yang menganggap unsur-unsur yang dikehendaki telah ada dalam sampel yang diambil.

\section{Pengukuran Parameter Fisika dan Kimia}

Suhu diukur dengan menggunakan termometer air raksa. Pengukuran suhu dilakukan pada suhu perairan dan

\footnotetext{
${ }^{\odot}$ Copyright by Management of Aquatic Resources (MAQUARES)
} 
udara pada titik sampling yang telah ditentukan. Termometer dimasukan ke dalam perairan kemudian catat suhu pada kertas hasil pengukuran. Derajat keasaman diukur pada setiap titik lokasi pengambilan sampel. Derajat keasaman diukur dengan menggunakan kertas $\mathrm{pH}$ atau kertas lakmus dengan cara memasukkan kertas indikator tersebut kedalam perairan lalu disamakan dengan indikator kontrol $\mathrm{pH}$. Pengukuran $\mathrm{pH}$ dilakukan pada permukaan perairan. Pengukuran salinitas menggunakan refraktometer. Sampel air diambil pada titik sampling yang telah ditentukan, kemudian air sempel diletakan pada refraktometer. Diamati skala yang ada pada refraktometer. Hasil pengukuran salinitas dicatat pada kertas hasil pengukuran. Pengukuran salinitas dilakukan secara in situ. Pengukuran oksigen terlarut dengan cara titrasi dimana langkah - langkahnya yaitu Mengambil sampel air dengan menggunakan botol BOD $125 \mathrm{ml}$ (tidak boleh ada udara yang masuk), lalu menambahkan 1 ml MnSO4 dan $1 \mathrm{ml} \mathrm{NaOH}$ dalam KI, tutup botol tersebut dan kocok hingga larutan homogen dan terjadi endapan, langkah selanjutnya menambahkan $1 \mathrm{ml} \mathrm{H}_{2} \mathrm{SO}_{4}$ pekat kemudian menutup botol BOD, kocok sampai endapan hilang dan larutan berwarna kuning. Setelah itu, memasukkan $50 \mathrm{ml}$ sampel ke dalam Erlenmeyer 250 ml, melakukan titrasi dengan $\mathrm{Na}_{2} \mathrm{~S}_{2} \mathrm{O}_{3} 0,025 \mathrm{~N}$ hingga larutan berwarna kuning muda. Menambahkan 2-3 tetes amilum sampai timbul warna biru, titrasi lagi dengan $\mathrm{Na}_{2} \mathrm{~S}_{2} \mathrm{O}_{3} \quad 0,025 \mathrm{~N}$ hingga bening. Hasil oksigen terlarut dihitung menggunakan rumus sebagai berikut:

$$
D O(m g / l)=\frac{\mathrm{ml} \text { titran } \times \mathrm{N} \text { titran } \times 8 \times 1000}{m l \text { sampel }}
$$

\section{Analisis Total Bakteri}

Analisis total bakteri pada perairan kawasan bermangrove dan tidak bermangrove menggunakan media Nutrient Agar. Media Nutrient Agar adalah media dasar bagi pertumbuhan bakteri dan biasa digunakan untuk menghitung total bakteri yang terdapat pada berbagai macam sampel, baik makanan, produk susu, air limbah maupun sampel lainnya.

Metode yang digunakan untuk menghitung total bakteri menurut Taslihan et al. (2004), dalam Kharisma dan Manan (2012) adalah metode TPC (Total Plate Count) dengan langkah sebagai berikut:

1. Membuat media Nutrient Agar. Larutkan Nutrient Agar 22 gram; KCl 0,75 gram; MgSO4 6,94 gram; $\mathrm{NaCl}$ 18,4 gram, kemudian dipanaskan sampai mendidih dan diaduk menggunakan magnetik stirer. Tujuannya adalah agar media Nutrient Agar benar benar terlarut dengan sempurna dalam aquades. Apabila media Nutrient Agar tidak terlarut dengan sempurna maka media yang dibuat tidak bisa memadat. Setelah media terlarut sempurna kemudian media disterilisasi dengan menggunakan autoclave selama 15 menit pada suhu $121^{\circ} \mathrm{C}$ dengan tekanan 1,5 ATM.

2. Membuatan larutan pengencer, larutan pengencer yang digunakan adalah Larutan Trisalt $(\mathrm{KCl} 0,75 \mathrm{~g}$; MgSO4 6,94 g; $\mathrm{NaCl} 23,4 \mathrm{~g}$ ) yang dilarutkan dalam 1000ml aquades. kemudian dipanaskan sampai mendidih dan diaduk menggunakan magnetik stirer. Pengenceran bertujuan untuk mengurangi jumalah mikroba tumbuh, sehingga mempermudah penghitungan koloni yang muncul. Alat yang digunakan adalah petri disk dan pipet dibersihkan kemudian dimasukkan ke nampan kemudian disterilisasi menggunakan oven selama 5 jam dengan suhu $140^{\circ} \mathrm{C}$.

3. Proses penanaman dilakukan dengan metode sebar, yaitu teknik penanaman bakteri dengan cara menuangkan ke permukaan media agar yang sudah padat, kemudian diratakan dengan spatula. Kelebihan teknik ini adalah bakteri yang tumbuh dapat tersebar merata pada permukaan media agar. Pada tahap ini membutuhkan suatu kondisi yang aseptis, apabila diabaikan maka kemungkinan media akan terkontaminasi mikroba dari luar. Oleh karena itu tangan dan tempat kerja harus disterilkan dengan alkohol 70\%. Untuk melakukan penanaman dilakukan dengan menyalakan api spiritus dengan jarak maksimal $30 \mathrm{~cm}$ dari api spirtus.

4. Proses inkubasi dilakukan dengan menyimpan biakan yang sudah ditanam pada media didalam inkubator selama 24 jam pada suhu $37^{\circ} \mathrm{C}$ yang merupakan suhu optimum untuk pertumbuhan bakteri. Untuk mempermudah proses penghitungan koloni digunakan colony counter.

5. Penghitungan bakteri yang sudah ditanam pada media NA dan sudah diinkubasi selama 24 jam dilakukan penghitungan dengan metode Total Plate Count (TPC). Metode TPC dilakukan dengan cara menghitung seluruh bakteri yang tumbuh pada media NA. Proses penghitungan bakteri tersebut menggunakan spidol untuk menandai bakteri yang sudah dihitung agar memudahkan dalam proses penghitungan.

$\mathrm{N}=$ Jumlah koloni per cawan petri $\times 10$

$\mathrm{N}$ adalah total bakteri $(\mathrm{CFU} / \mathrm{ml})$ dan 10 adalah jumlah sampel air yang ditanam pada cawan petri. Kemudian setiap 1 kali pengenceran, total bakteri dikali 10 .

5. Analisis Bahan Organik

Metode yang digunakan dalam pengukuran TOM atau bahan organik total berdasarkan SNI 06-6989.22-2004 langkah-langkahnya adalah sebagai berikut: Memasukkan $100 \mathrm{ml}$ sampel ke dalam Erlenmeyer $300 \mathrm{ml}$. Menambahkan KMnO4 0,01 N beberapa tetes hingga berwarna merah muda. Menambahkan $5 \mathrm{ml} \mathrm{H} 2 \mathrm{SO} 48 \mathrm{~N}$. Memanaskan di atas pemanas listrik pada suhu $105^{\circ} \mathrm{C} \pm 2{ }^{\circ} \mathrm{C}$ hingga menguapMenambahkan 10 ml larutan KMnO4 0,01N kemudian dipanaskan hingga mendidih selama 10 menit. Menambahkan $10 \mathrm{ml}$

\footnotetext{
${ }^{\circledR}$ Copyright by Management of Aquatic Resources (MAQUARES)
} 
asam oksalat $0,01 \mathrm{~N}$ hingga warna bening. Mentitrasi menggunakan $\mathrm{KMnO} 40,01 \mathrm{~N}$ hingga terjadi perubahan warna dari bening merah muda. Mencatat volume pemakaian KMnO4. Rumus untuk menghitung bahan organik total dalam metode TOM menurut SNI 06-6989.22-2004 :

$$
\operatorname{TOM}(\mathrm{mg} / \mathrm{l})=\frac{(X-Y) \times 31,6 \times 0,01 \times 1000}{\mathrm{ml} \mathrm{sampel}}
$$

Keterangan:

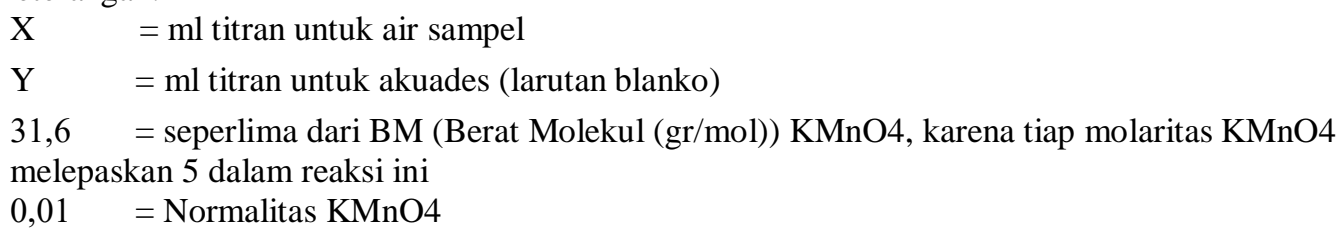

\section{Analisis data}

Analisis data menggunakan T-test untuk mengetahui perbandingan total bakteri pada area bermangrove dan tidak bermangrove. Dalam pengolahan data ini digunakan SPSS versi 16.0. Data yang digunakan dalam T-test sebelumnya diuji dengan uji normalitas untuk mengetahui data tersebut terdistribusi normal atau tidak. Kemudian dilanjutkan dengan Analisis data menggunakan Principal Component Analysis (PCA) untuk mengetahui hubungan atau faktor-faktor yang mempengaruhi kelimpahan total bakteri pada wilayah tersebut. Dalam pengolahan data ini digunakan Statistica 6.

\section{HASIL DAN PEMBAHASAN}

\subsection{Hasil}

a. Gambaran Umum Lokasi Penelitian
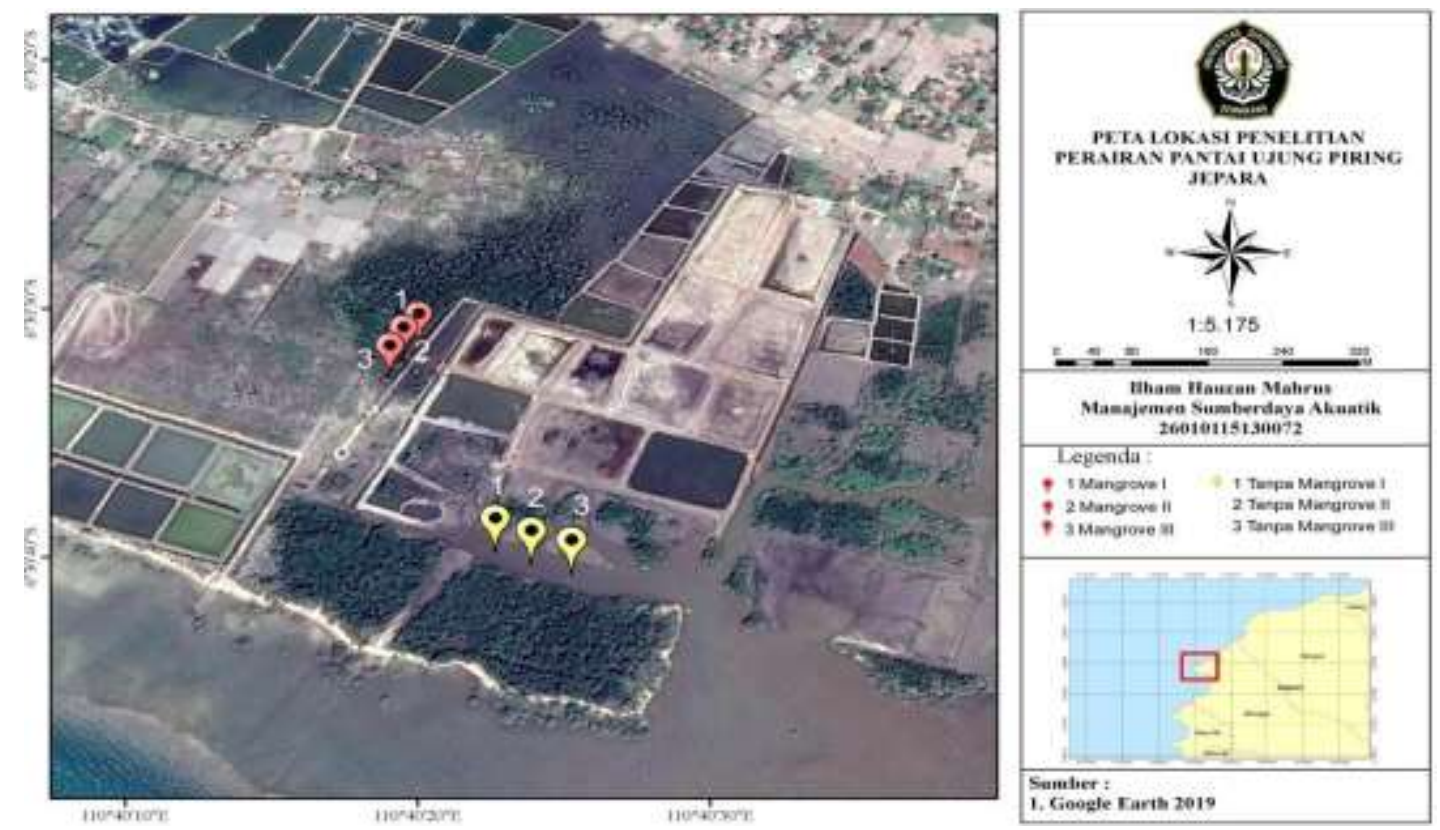

Penelitian ini dilakukan di kawasan mangrove Pantai Ujung Piring, Desa Jambu, Kecamatan Mlonggo, Kabupaten Jepara. Kawasan mangrove Pantai Ujung Piring Pantai Ujung Piring terletak di dekat wilayah pertambakan, pemukiman, dan juga proyek pembukaan wilayah tambak baru di sekitar lokasi pantai dan mangrove. Jenis mangrove yang mendominasi di pantai Ujung Piring, Jepara ini adalah Rhizophora sp. Menurut Mauludin et al. (2018), berdasarkan hasil pengamatan bahwa tipe substrat pada lokasi pantai Jambu adalah lanau berpasir, lokasi pantai Blebak yaitu pasir berlanau dan lokasi pantai Sekuro yaitu lanau berpasir, lokasi pantai Blebak dengan tipe pasir berlanau diduga lahan mangrove tersebut bekas lahan tambak.

\section{b. Total Bakteri}

Tabel 1. Hasil Perhitungan Total Bakteri (CFU/ml) di Perairan Pantai Ujung Piring, Jepara

Titik Pengulangan I $\quad$ Pengulangan II Pengulangan III




\begin{tabular}{cccc}
\hline M1 & $5,5 \times 10^{5}$ & $3,4 \times 10^{5}$ & $2,5 \times 10^{5}$ \\
M2 & $8,0 \times 10^{3}$ & $2,6 \times 10^{3}$ & $3,5 \times 10^{3}$ \\
M3 & $5,0 \times 10^{3}$ & $3,2 \times 10^{3}$ & $2,5 \times 10^{3}$ \\
\hline Rata-rata & $6,167 \times 10^{5}$ & $3,067 \times 10^{5}$ & $2,833 \times 10^{5}$ \\
& & & \\
TM1 & $2,2 \times 10^{3}$ & $1,4 \times 10^{3}$ & $3,9 \times 10^{3}$ \\
TM2 & $4,6 \times 10^{3}$ & $1,7 \times 10^{3}$ & $1.7 \times 10^{3}$ \\
TM3 & $2,0 \times 10^{3}$ & $2,6 \times 10^{3}$ & $3,6 \times 10^{3}$ \\
\hline Rata-rata & $2,933 \times 10^{3}$ & $1,9 \times 10^{3}$ & $3,067 \times 10^{3}$ \\
\hline
\end{tabular}

Hasil yang diperoleh dari perhitungan total bakteri pada pengulangan pertama kawasan bermangrove ratarata $6,167 \times 10^{3} \mathrm{CFU} / \mathrm{ml}$, sedangkan tidak bermangrove $2,933 \times 10^{3} \mathrm{CFU} / \mathrm{ml}$. Total bakteri pada pengulangan kedua pada kawasan bermangrove diperoleh rata-rata $3,067 \times 10^{3} \mathrm{CFU} / \mathrm{ml}$ dan tidak bermangrove $1,9 \mathrm{x}$ $10^{3} \mathrm{CFU} / \mathrm{ml}$. Hasil pengulangan kedua mengalami penuruan dikarenakan cuaca saat pengambilan sampel setelah hujan dengan intensitas tinggi pada malam harinya. Pengulangan ketiga diperoleh hasil perhitungan total bakteri daerah bermangrove $2,833 \times 10^{3} \mathrm{CFU} / \mathrm{ml}$ dan tidak bermangrove $3,067 \times 10^{3} \mathrm{CFU} / \mathrm{ml}$.

c. Perbedaan Total Bakteri Di Perariran Bermangrove dan Tidak Bermangrove

Tabel 2. Hasil Uji Normalitas Kolmogrov-Smirnov

\begin{tabular}{llccc}
\hline No & Titik sampling & N & Standar Deviasi & Sig \\
\hline 1 & Mangrove & 9 & $1.835,6$ & 0,487 \\
2 & Tidak Bermangrove & 9 & $1.132,4$ & 0,845 \\
\hline
\end{tabular}

Hasil uji normalitas Kolmogrov-Smirnov, data yang diperoleh menunjukkan nilai signifikan. Nilai pada kawasan bermangrove yaitu 0,487 dan nilai kawasan tidak bermangrove yaitu 0,845 . Kedua data yang diperoleh memiliki nilai lebih besar dari $\alpha$ yaitu 0,05 . Sehingga data yang diperoleh dikategorikan terdistribusi secara normal. Kemudian untuk mengetahui perbedaan total bakteri pada kawasan bermangrove dan tidak bermangrove digunakan T-test. Hasil uji perbedaan menggunakan T-test disajikan pada Tabel 3.

Tabel 3. Hasil Paired Sample T-tes

\begin{tabular}{lccc}
\hline Total bakteri & $\mathrm{N}$ & $\mathrm{df}$ & Sig. (2-tailed) \\
\hline $\begin{array}{l}\text { Bermangrove } \\
\begin{array}{l}\text { Tidak } \\
\text { bermangrove }\end{array}\end{array}$ & 9 & 8 & 0,048 \\
\hline
\end{tabular}

Hasil T-test nilai Sig. (2-tailed) yaitu 0,048 lebih kecil dari $\alpha 0,05$ atau $0,048<0,05$. Maka H0 ditolak dan H1 diterima, sehingga dapat disimpulkan bahwa ada perbedaan total bakteri pada kawasan bermangrove dengan tidak bermangrove di perairan pantai Ujung Piring, Jepara.

\section{d. Hubungan Antara Total Bakteri dengan Bahan Organik}

Total bakteri yang terdapat pada sampel air berbanding lurus dengan konsentrasi bahan organik. Semakin tinggi konsentrasi bahan organik pada suatu perairan maka semakin tinggi pula total bakteri yang terdapat pada perairan tersebut. Hasil analisi PCA (Principal Component Analysis) yang telah dilakukan, diperoleh hasil korelasi antara total bakteri pada perairan bermangrove dengan bahan organik yaitu $r=0,927805$. Sedangkan pada perairan tidak bermangrove dengan bahan organik yaitu $r=0,875377$. Hasil yang diperoleh dari analisis tersebut mendekati angka 1 yang berarti mempunyai hubungan yang kuat. Kemudian dari hasil proyeksi variabel, pada kuadran IV (M, Bahan Organik M dan Bahan Organik TM) merupakan variabel yang berbanding lurus dan berbanding terbalik dengan kuadran II (Nitrat M) Hal ini dapat dilihat dari hasil analisis PCA (Principal Component Analysis) disajikan pada Tabel 4 dan Gambar 2.

Tabel 4. Hasil Analisis PCA (Principal Component Analysis)

\begin{tabular}{ccccc}
\hline & M & TM & $\begin{array}{c}\text { Bahan } \\
\text { Organik M }\end{array}$ & $\begin{array}{c}\text { Bahan } \\
\text { organik TM }\end{array}$ \\
\hline $\mathbf{M}$ & 1,000000 & 0,348782 & 0,927805 & 0,758399 \\
TM & 0,348782 & 1,000000 & $-0,026036$ & 0,875377 \\
\hline
\end{tabular}

${ }^{\circledR}$ Copyright by Management of Aquatic Resources (MAQUARES) 


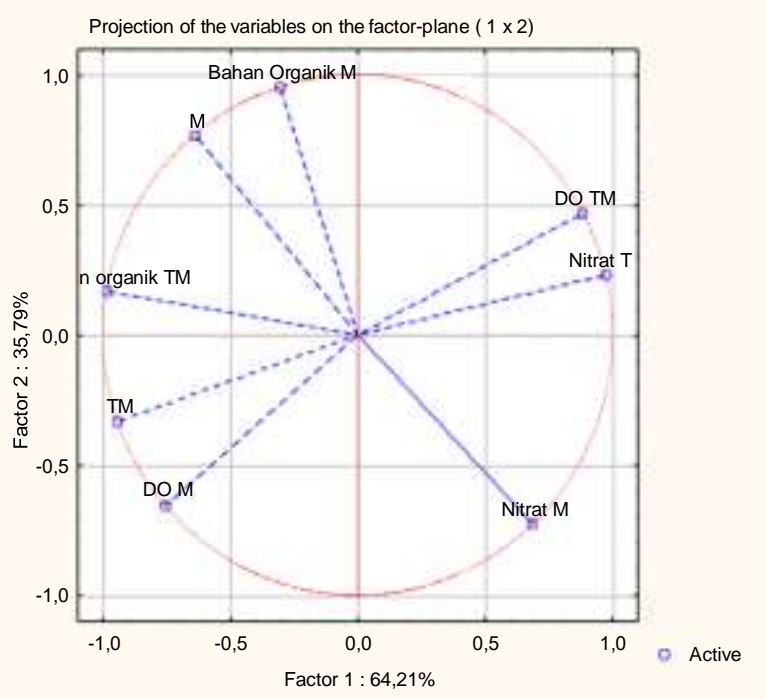

Gambar 2.Hasil Analisis PCA, Proyeksi Variabel

\section{e. Parameter Fisika Kimia}

Hasil yang diperoleh dari pengukuran parameter fisika dan kimia pada perairan bermangrove dan tidak bermangrove Pantai Ujung Piring, Jepara disajikan pada Tabel 5.

Tabel 5. Hasil pengukuran parameter fisika dan kimia di Perairan Pantai Ujung Piring, Jepara

\begin{tabular}{lllllll}
\hline Pengulangan & Titik & Suhu $\left({ }^{\circ} \mathbf{C}\right)$ & pH & $\begin{array}{l}\text { Salinitas } \\
(\mathbf{p p t})\end{array}$ & $\begin{array}{l}\text { DO } \\
(\mathbf{m g} / \mathbf{l})\end{array}$ \\
\cline { 2 - 6 } Pampling & Air & Udara & & 22 & 2,36 \\
& M1 & 29 & 31 & 7 & 22 & 1,36 \\
& M2 & 29 & 31 & 7 & 22 & 4,60 \\
& M3 & 29 & 31 & 7 & 3,00 \\
& TM1 & 31 & 31 & 7 & 30 & 3,60 \\
\hline \multirow{5}{*}{ Pengulangan I } & TM2 & 31 & 31 & 7 & 30 & 2,28 \\
& TM3 & 31 & 31 & 7 & 30 & 2,52 \\
& M1 & 30 & 29 & 7 & 21 & 2,64 \\
& M2 & 30 & 29 & 7 & 21 & 2,64 \\
& M3 & 30 & 29 & 7 & 21 & 5,80 \\
& TM1 & 32 & 29 & 7 & 30 & 3,00 \\
\hline \multirow{5}{*}{ Pengulangan III } & TM2 & 32 & 29 & 7 & 30 & 1,68 \\
& TM3 & 32 & 29 & 7 & 30 & 1,60 \\
& M1 & 29 & 30 & 7 & 23 & 2,40 \\
& M2 & 29 & 30 & 7 & 23 & 3.32 \\
& TM1 & 29 & 30 & 7 & 23 & 4,00 \\
& TM2 & 29 & 30 & 7 & 30 & 2,92 \\
\hline RMata-rata & 29 & 30 & 7 & 30 & 2,91 \\
\hline
\end{tabular}

Suhu air pada pengulangan pertama di lokasi bermangrove yaitu $29^{\circ} \mathrm{C}$ dan tidak bermangrove yaitu $31^{\circ} \mathrm{C}$, sedangkan suhu udara yaitu $31^{\circ} \mathrm{C}$. Kemudian suhu air pada pengulangan kedua di lokasi bermangrove yaitu $30^{\circ} \mathrm{C}$ dan tidak bermangrove yaitu $32^{\circ} \mathrm{C}$, sedangkan suhu udara yaitu $29^{\circ} \mathrm{C}$. Naiknya suhu air pada pengulangan kedua dikarenakan sinar matahari yang sangat terik setelah terjadinya hujan pada malam harinya, kemudian suhu udara yang turun diakibatkan angin yang cukup kencang. Suhu air pada pengulangan ketiga di lokasi bermangrove dan tidak bermangrove yaitu $29^{\circ} \mathrm{C}$, sedangkan suhu udara yaitu $30^{\circ} \mathrm{C}$.

Nilai pH yang diperoleh dari lokasi bermangrove dan tidak bermangrove pada pengulangan pertama yaitu 7 . Kemudian pengulangan kedua, nilai $\mathrm{pH}$ pada kedua lokasi yaitu 7. Kemudian pada pengulangan ketiga, nilai $\mathrm{pH}$ pada kedua lokasi yaitu 7 .

Salinitas air pada pengulangan pertama di lokasi bermangrove yaitu 22 ppt dan tidak bermangrove 30 ppt. Kemudian pada pengulangan kedua nilai salinitas pada lokasi bermangrove yaitu 21 ppt dan tidak bermangrove 30 ppt. Tununnya nilai salinitas pada pengulangan kedua di lokasi bermangrove dipengaruhi oleh hujan dengan intensitas tinggi pada malam harinya. Sedangkan pada pengulangan ketiga di lokasi bermangrove yaitu 23 ppt dan tidak bermangrove yaitu 30 ppt. Perbedaan nilai salinitas pada kedua lokasi ini dikarenakan titik sampling

\footnotetext{
${ }^{\odot}$ Copyright by Management of Aquatic Resources (MAQUARES)
} 
perairan tidak bermangrove lebih dekat dengan laut, sehingga nilai pada lokasi tidak bermangrove lebih tinggi.

Nilai oksigen terlarut pada pengulangan pertama yaitu 1,36-4,68 (mg/l). Kemudian pada pengulangan kedua yaitu 2,28-5,80 (mg/l) dan pada pengulangan ketiga yaitu 1,60-4,00 (mg/l). Nilai oksigen terlarut yang terdapat pada lokasi tidak bermangrove lebih tinggi dari lokasi bermangrove, baik pada pengulangan pertama, kedua dan ketiga.

\section{f. Bahan Organik dan Nitrat}

Hasil yang diperoleh dari perhitungan kadar bahan organik dan nitrat pada perairan bermangrove dan tidak bermangrove Pantai Ujung Piring, Jepara disajikan pada Tabel 6.

Tabel 6. Hasil Perhitungan Kadar Bahan Organik dan Nitrat di Perairan Pantai Ujung Piring, Jepara

\begin{tabular}{cc}
\hline Titik Sampling & Bahan Organik (mg/l) \\
\hline M1 & 162,6 \\
M2 & 117,3 \\
M3 & 82,87 \\
TM1 & 121,9 \\
TM2 & 106,1 \\
TM3 & 115,7
\end{tabular}

Hasil yang diperoleh pada tabel 3, kandungan bahan organik terendah terdapat di lokasi M3 yaitu 82,87 mg/l, sedangkan kandungan bahan organik tertinggi terdapat di lokasi M1 yaitu 162,6 mg/l. Hasil nitrat dari kedua lokasi diperoleh nilai sebesar $0,01-0,02 \mathrm{mg} / \mathrm{l}$.

\subsection{Pembahasan}

\section{a. Perbedaan Total Bakteri Perairan Bermangrove dan Tidak Bermangrove}

Hasil penghitungan total bakteri perairan pada kawasan bermangrove dan tidak bermangrove, yang dilakukan pada sembilan titik dan dilakukan pengulangan sebanyak tiga pengulangan. Berdasarkan T-test yang telah dilakukan, diperoleh hasil Sig. (2-tailed) yaitu 0,048 lebih kecil dari $\alpha 0,05$ atau 0,048 $<0,05$. Maka $\mathrm{H}_{0}$ ditolak dan $\mathrm{H}_{1}$ diterima, sehingga dapat disimpulkan bahwa ada perbedaan total bakteri pada kawasan bermangrove dengan tidak bermangrove di perairan Pantai Ujung Piring, Jepara. Diketahui total bakteri pada lokasi bermangrove memiliki jumlah lebih tinggi dibandingkan dengan lokasi tidak bermangrove. Kawasan bermangrove pada perairan pantai Ujung Piring didominasi oleh jenis Rhizophora sp. dengan total bakteri pada kawasan bermangrove sebanyak $2,5 \times 10^{3} \mathrm{CFU} / \mathrm{ml}$ hingga $8,0 \times 10^{3} \mathrm{CFU} / \mathrm{ml}$. Sedangkan pada kawasan tidak bermangrove $1,4 \times 10^{3} \mathrm{CFU} / \mathrm{ml}$ hingga $4,6 \times 10^{3} \mathrm{CFU} / \mathrm{ml}$. Nilai total bakteri pada pengulangan kedua mengalami penurunan dikarenakan kondisi cuaca pada saat pengambilan sampel dilakukan setelah hujan dengan intensitas tinggi pada malam harinya.

Hasil penelitian yang dilakukan oleh Tyas et al., (2018), bahwa wilayah bermangrove yang didominasi oleh mangrove jenis Avicennia sp. atau yang biasa dikenal api-api ini memiliki total jumlah bakteri sedimen berkisar antara $0,26 \times 10^{4}$ hingga $0,80 \times 10^{4} \mathrm{CFU} / g r$. Sementara pada area tidak bermangrove total bakteri yang didapat jauh lebih tinggi yakni $1,35 \times 10^{4} \mathrm{CFU} / g r$. Perbedaan total bakteri pada kedua area tersebut dapat disebabkan oleh beberapa faktor yaitu kondisi lingkungan seperti kondisi fisika (suhu, arus, kedalaman, kecerahan); kimia $(\mathrm{pH}, \mathrm{DO})$ dan bahan organik. Perbedaan jumlah bakteri pada kedua kawasan tersebut juga ada kaitannya dengan jenis mangrove yang hidup pada lokasi penelitian. Mangrove yang hidup adalah jenis Avicennia sp. dengan salinitas yang cukup tinggi yakni berkisar pada 30 ppt. Kondisi ini memungkinkan terjadinya penurunan populasi bakteri pada kawasan tersebut.

Total bakteri pada kedua kawasan tersebut menunjukkan perbedaan, hal tersebut dapat disebabkan oleh beberapa faktor. Faktor yang menyebabkan perbedaan total bakteri pada kedua kawasan tersebut yaitu kondisi fisika kimia (suhu, salinitas, pH, oksigen terlarut), kandungan bahan organik, kadar nitrat dan kondisi cuaca pada saat pengambilan sampel. Pengambilan sampel pada pengulangan kedua dilakukan setelah hujan pada malam harinya, sehingga total bakteri yang didapat pada pengambilan sampel kedua menurun. Menurut Kosasih et al. (2009), bahwa arah aliran air berkaitan dengan pergerakan bakteri dimana pergerakannya akan mengikuti arah aliran air tersebut sehingga pengambilan sampel yang dilakukan setelah terjadi hujan kemungkinan besar akan mempengaruhi jumlah bakteri pada sampel yang diambil. Hal ini diperkuat juga oleh (Marwan et al., 2015) yang menyatakan bahawa hasil kisaran nilai total bakteri pada pengulangan kedua lebih rendah dibandingkan dengan hasil dari pengulangan pertama. Hal ini dikarenakan turunnya hujan saat pengambilan sampel pada sampling kedua, sehingga pada sampling kedua menghasilkan total bakteri yang lebih sedikit karena turunnya hujan menyebabkan berkurangnya bakteri pada perairan. Hal ini dikarenakan sedikitnya cahaya yang masuk pada badan air dan juga suhu tinggi menjadi kurang optimal bagi kehidupan bakteri.

\section{b. Hubungan Total Bakteri dengan Bahan Organik}

Hasil analisis PCA (Principal Component Analysis) yang telah dilakukan untuk mengetahui hubungan antara total bakteri dengan bahan organik, dapat diketahui bahwa bahan organik mempunyai hubungan yang erat

\footnotetext{
${ }^{\circledR}$ Copyright by Management of Aquatic Resources (MAQUARES)
} 
dengan total bakteri. Nilai korelasi yang didapat dari analisis PCA (Principal Component Analysis) yaitu $\mathrm{r}=0,98$ untuk total bakteri perairan bermangrove dan $r=0,87$ untuk total bakteri perairan tidak bermangrove. Sehingga dapat dikatakan hubungan antara total bakteri dengan bahan organik di perairan bermangrove dan tidak bermangrove pantai Ujung Piring, Jepara mempunyai korelasi yang kuat.

Hasil penelitian yang dilakukan oleh Kristiawan et al. (2014), bahwa tingkat keeratan hubungan bakteri dan total organik terlarut adalah sebesar $94 \%$. Hal ini dapat diartikan bahwa antara total bakteri dengan bahan organik total yang terdapat di perairan muara Kali Wiso memiliki hubungan yang sangat signifikan karena tingkat keeratannya mendekati nilai persentase 100. Menurut Mufaidah et al. (2016), berdasarkan hasil analisis menunjukkan korelasi tidak terlalu kuat antara total bakteri pada sedimen dan bahan organik total pada sedimen, dikarenakan nilai $r$ cukup yaitu $0,511(R 2=0,262)$. Menurut Sugiyono (2012) bahwa nilai $0,4<r \leq 0,69$ maka memiliki korelasi cukup. Nilai determinasi koefisien penentu $(\mathrm{KP})$ sebesar $(\mathrm{R} 2=0,262)$ yang artinya $26,2 \%$ bahan organik mempengaruhi total bakteri dan sisanya 73,8\% di pengaruhi oleh variabel lain. Hal ini diperkuat oleh Boyd (1988) dalam Effendi (2003) yang menyatakan bahwa oksidasi bahan organik di perairan dipengaruhi oleh suhu, derajat keasaman, oksigen terlarut, jenis bahan organik dan nitrogen sehingga semakin banyak bahan organik serta didukung faktor-faktor lain maka akan menambah total bakteri untuk mengoksidasi bahan organik.

Konsentrasi bahan organik yang berbanding lurus dengan total bakteri pada perairan pantai Ujung Piring, Jepara yang menandakan semakin tinggi bahan organik di suatu perairan maka semakin tinggi juga total bakteri yang terdapat pada perairan tersebut. Menurut Zulkifli et al. (2011), bahwa tingginya kandungan bahan organik akan mempengaruhi kelimpahan mikroorganisme maupun makroorganisme, dimana terdapat organismeorganisme tertentu yang tahan terhadap tingginya kandungan bahan organik tersebut, sehingga dominansi oleh spesies tertentu dapat terjadi. Kandungan bahan organik yang tinggi akan mempengaruhi tingkat keseimbangan perairan.

Parameter Fisika dan Kimia Suhu

Hasil dari pengukuran suhu yang dilakukan pada kawasan bermangrove dan tidak bermangrove yaitu $29^{\circ} \mathrm{C}$ $30^{\circ} \mathrm{C}$, sedangkan kawasan tidak bermangrove cenderung lebih tinggi yaitu $29^{\circ} \mathrm{C}-32^{\circ} \mathrm{C}$. Nilai tersebut masih tergolong suhu optimum untuk bakteri. Kemudian nilai suhu pada suatu perairan dapat disebabkan oleh beberapa faktor, salah satunya yaitu jumlah intensitas cahaya yang masuk pada kawasan tersebut. Kawasan bermangrove memiliki intensitas cahaya yang lebih sedikit dibandingkan kawasan tidak bermangrove, sehingga suhu pada kedua kawasan ini berbeda. Kemudian cuaca saat pengukuran juga mempengaruhi nilai suhu, pengukuran suhu pada pengulangan ketiga dengan kondisi berawan, sehingga cuaca tidak terlalu panas. Variasi suhu ini dapat diakibatkan oleh cuaca pada saat pengambilan sampel (Putra, 2014).

Hasil penelitian yang dilakukan oleh Yulma et al. (2017), hasil pengukuran suhu di perairan KKMB berkisar $26,9^{\circ} \mathrm{C}-30^{\circ} \mathrm{C}$, suhu yang diperoleh dalam penelitian ini masih berada dalam kisaran yang baik untuk proses dekomposisi. Hal ini diperkuat oleh Hanafiah (2005) dalam Mufaidah et al. (2016), bahwa temperatur mempengaruhi laju dekomposisi bahan organik sebagai dampak pengaruhnya terhadap jenis mikroba yang dominan. Umumnya proses dekomposisi secara maksimum berlangsung pada temperatur $30-35^{\circ} \mathrm{C}$ atau hingga $45^{\circ} \mathrm{C}$. Sedangkan pada temperatur dibawah $30^{\circ} \mathrm{C}$ atau di atas $45^{\circ} \mathrm{C}$ proses dekomposisi terhambat. Temperatur pada penelitian berkisar $28^{\circ} \mathrm{C}-31^{\circ} \mathrm{C}$.

Menurut Indriani (2008) yang menyatakan bahwa suhu optimum untuk bakteri berkisar $27-36$ 0C. Kisaran suhu tersebut sangat baik untuk proses penguraian dengan asumsi daun mangrove sebagai dasar metabolisme. Hal ini diperkuat oleh Yulma et al. (2017), bahwa suhu merupakan parameter fisika yang mempengaruhi sifat fisiologi mikroorganisme yang hidup di lingkungan tersebut. Suhu sangat berpengaruh terhadap kerja enzim, semakin tinggi suhu maka kerja enzim akan semakin cepat, maka penguraian serasah daun mangrove juga akan semakin meningkat. Setiap peningkatan suhu sebesar $10{ }^{\circ} \mathrm{C}$ akan meningkatkan laju metabolisme organisme menjadi dua kali lipat, akan tetapi penambahan suhu maksimal dapat mematikan mikroorganisme pendegradasi serasah.

\section{Salinitas}

Pengukuran salinitas pada kawasan bermangrove dan tidak bermangrove menunjukkan hasil yang berbeda. Kadar salinitas pada kawasan bermangrove berkisar antara 21 ppt hingga 23 ppt. Sedangkan pada kawasan tidak bermangrove kadar salinitas yaitu 30 ppt. Nilai salinitas yang berbeda ini disebabkan karena kawasan tidak bermangrove merupakan daerah yang lebih dekat dengan pantai, sehingga kadar salinitasnya tinggi. Sedangkan pada kawasan bermangrove merupakan daerah yang masih dipengaruhi oleh aktivitas dari daratan. Sehingga kadar salnitas pada kawasan tidak bermangrove cenderung lebih rendah. Kadar salinitas pada kedua kawasan tersebut masih tergolong optimum untuk kawasan ekosistem mangrove.

Hasil penelitian yang dilakukan oleh Yunasfi (2006) dalam Yulma et al. (2017), bahwa keanekaragaman bakteri serasah daun Avicennia marina yang mengalami dekomposisi pada berbagai tingkat salinitas di Teluk Tapian Nauli dengan hasil pada tingkat salinitas 10-20 ppt ditemukan 16 jenis bakteri, 20-30 ppt ditemukan 12 bakteri dan $>30$ ppt ditemukan 9 bakteri. Hal ini menunjukan bahwa semakin tingginya salinitas maka kelimpahan bakteri semakin berkurang.

Nilai salinitas yang cenderung lebih tinggi menyebabkan rendahnya aktivitas bakteri, sehingga nilai total

\footnotetext{
${ }^{\odot}$ Copyright by Management of Aquatic Resources (MAQUARES)
} 
bakteri cenderung lebih sedikit. Menurut Hal ini diperkuat oleh Hrenovic et al. (2003) dalam Yulma et al. (2017), yang menyatakan bahwa bertambahnya salinitas akan memberikan efek negatif terhadap kelimpahan dan keanekaragaman bakteri. Tingginya tingkat salinitas mampu menghambat pertumbuhan koloni bakteri sehingga menyebabkan tingkat aktivitas bakteri sangat rendah. Hal ini diperkuat oleh Haris (2014) yang menyatakan bahwa nilai salinitas optimum yang dibutuhkan mangrove untuk tumbuh berkisar antara 10-30 ppt, Salinitas secara langsung dapat mempengaruhi laju pertumbuhan dan zonasi mangrove, Salinitas air akan meningkat jika pada siang hari cuaca panas dan dalam keadaan pasang.

\section{DO}

Hasil pengukuran kadar oksigen pada kawasan bermangrove dan tidak bermangrove perairan pantai Ujung Piring, Jepara menunjukkan nilai yang rendah yaitu berkisar antara 1,36 - 5,8 ml/l. Nilai yang rendah ini disebabkan oleh beberapa faktor, salah satunya yaitu karena mangrove hidup pada daerah yang memiliki lumpur yang tebal sehingga kadar oksigennya semakin sedikit. Kemudian pengukuran kadar oksigen yang dilakukan pagi hari sehingga kadar oksigen terlalut rendah atau dalam kondisi minimum.

Hasil penelitian yang dilakukan oleh Malik (2013) bahwa oksigen terlarut (DO) di perairan Kabupaten Barru berkisar antara 7,0 - 8,0 mg/l, berada di atas ambang batas minimum. Kelarutan oksigen di dalam air merupakan fungsi dari suhu dan salinitas. Kelarutan oksigen berkolerasi negative terhadap suhu dan salinitas perairan. Kelarutan oksigen semakin rendah dengan meningkatnya suhu dan salinitas. pengukuran DO yang dilakukan pada saat pasang pagi hari (pukul 06.00 - 07.00), maka hasil yang di peroleh akan lebih rendah bahkan mungkin DO berada pada titik minimum, karena tidak terjadi proses fotosintesis sebelumnya dan DO yang ada digunakan untuk proses respirasi.

Hal ini juga diperkuat oleh Halidah (2010) yang menyatakan bahwa semakin tebal lumpur maka semakin kurang oksigen yang tersedia bagi perakaran mangrove. Salah satu fungsi akar tunjang pada mangrove adalah untuk menyerap udara pada kondisi anoksik.

\section{c. Bahan Organik Terlarut}

Kandungan bahan organik yang diperoleh dari kawasan bermangrove dan tidak bermangrove, menunjukkan hasil 82,87 mg/l - 162,6 mg/l. Nilai bahan organik pada kawasan perairan Pantai Ujung Piring, Jepara dapat disebabkan oleh beberapa faktor. Salah satunya yaitu penguraian serasah mangrove dan organisme yang mati, yang nantinya akan diubah oleh bakteri menjadi anorganik atau zat hara. Zat hara merupakan senyawa yang berperan penting dalam perkembangan hidup organisme. Tingginya kandungan bahan organik terlarut pada kawasan bermangrove berbanding lurus dengan total bakteri, dimana semakin banyak kandungan bahan organiknya maka semakin banyak total bakteri yang terdapat pada perairan bermangrove.

Hasil penelitian yang dilakukan oleh Sa'diya (2018) bahwa sebaran bahan organik pada kawasan luar mangrove didapatkan hasil 10,993\% sedangkan pada kawasan di dalam mangrove sebesar 15,971\%, hal ini diduga juga menyebabkan perbedaan jumlah bakteri pada area bermangrove dan tidak bermangrove. Bahan organik serta faktor fisika dan kimia lainnya dapat berpengaruh terhadap jumlah bakteri. Hal ini juga diperkuat oleh Boyd (1988) dalam Effendi (2003), oksidasi bahan organik di perairan dipengaruhi oleh suhu, derajat keasaman, oksigen terlarut, jenis bahan organik, dan nitrogen sehingga semakin banyak bahan organik serata didukung faktor- faktor lain maka akan dapat menambah total bakteri untuk dapat mengoksidasi bahan organik.

Menurut Endang et al. (2019), bahwa keberadaan bahan organik dalam suatu perairan memiliki peran penting yaitu sebagai sumber nutrien bagi biota yang berada di perairan tersebut. Semakin tinggi kandungan bahan organik maka laju dekomposisinya juga semakin tinggi.

\section{KESIMPULAN}

Berdasarkan penelitian yang telah dilakukan di perairan bermangrove dan tidak bermangrove Pantai Ujung Piring Jepara, dapat diambil kesimpulan nilai total bakteri yang diperoleh pada perairan pantai Ujung Piring, Jepara termasuk dalam kategori rendah. kemudian terdapat hubungan yang kuat antara total bakteri dengan bahan organik dan Terdapat perbedaan total bakteri pada kawasan bermangrove dengan tidak bermangrove di perairan Pantai Ujung Piring, Jepara.

\section{UCAPAN TERIMAKASIH}

Penulis mengucapkan terimakasih kepada seluruh pihak yang telah membantu dalam proses penyusunan dan memberikan semangat, kritik dan saran dalam pelaksanaan penelitian ini.

\section{DAFTAR PUSTAKA}

Dewi, A. K., Meylina, L., \& Rusli, R. (2017). Isolasi Bakteri Dari Tanah Mangrove Rhizopora sp. di Kota Bontang. Mulawarman Pharmaceuticals Conferences, 5(1):59-68.

\footnotetext{
${ }^{\odot}$ Copyright by Management of Aquatic Resources (MAQUARES)
} 
Effendi, H. (2003). Telaah Kualitas Air. Bagi Pengelolaan Sumber Daya dan Lingkungan Perairan. Penerbit Kanasius, Jogjakarta.

Endang, H., Sari, L. K., \& Setijanto. (2019). Landscaping Mangrove Berdasarkan Kualitas Air (Studi Kasus di Laguna Segara Anakan dan Pulau Meranti). IOP Conf. Series: Earth and Environmental Science, 2(1):20-28.

Halidah. (2010). Pertumbuhan Rhizophora mucronata pada Berbagai Kondisi Substrat di Kawasan Rehabilitasi Mangrove Sinjai Timur Sulawesi Selatan. Jurnal Penelitian Hutan dan Konservasi Alam, 7(4):399-412.

Haris, R. (2014). Keanekaragaman Vegetasi Dan Satwa Liar. Jurnal Bionature, 15(2), 117-122.

Indriani, Y. (2008). Produksi dan Laju Dekomposisi Serasah Daun Mangrove Api-api (Avicennia marina Forssk. Vierh) di Desa Lontar, Kecamatan Kemiri, Kabupaten Tangerang, Provinsi Banten. [Skripsi]. Fakultas Perikanan dan Ilmu Kelautan. Institut Pertanian Bogor. Bogor.

Kharisma, A., dan A. Manan. (2012). Kelimpahan Bakteri Vibrio sp. pada Air Pembesaran Udang Vannamei (Litopenaeus vannamei) sebagai Deteksi Dini Serangan Penyakit Vibriosis. Jurnal Ilmiah Perikanan Dan Kelautan, 4(2):129-134.

Kristiawan, D., N. Widyorini., dan Haeruddin. (2014). Hubungan Total Bakteri dengan Kandungan Bahan Organik Total di Muara Kali Wiso, Jepara. Diponegoro Journal of Maquares, 3(4):24-33.

Malik, A. (2013). Analisis Kualitas Air pada Kerapatan Mangrove yang Berbeda di Kabupaten Barru. Jurnal Ilmu Perikanan, 2(2):159-163.

Marwan, A. H., Widyorini, N., \& Nitisupardjo, M. (2015). Hubungan Total Bakteri dengan Kandungan Bahan Organik Total di Muara Sungai Babon, Semarang. Diponegoro Journal of Maquares, 4(3):171-179.

Mauludin, M. R., Azizah, R., Pribadi, R., \& Suryono, S. (2018). Komposisi dan Tutupan Kanopi Mangrove di Kawasan Ujung Piring Kabupaten Jepara. Buletin Oseanografi Marina, 7(1):29-36

Mufaidah, Z., Supriharyono, \& Muskananfola, M. R. (2016). Hubungan Kandungan Bahan Organik dengan Total Bakteri di Sedimen Muara Sungai Wiso, Jepara. Diponegoro Journal of Maquares, 5(4):265-274.

Nasution, R. (2003). Teknik Pengambilan Sampling. Fakultas Kesehatan Masyarakat Universitas Sumatra Utara.

Purnomo, P. W., N. Widyorini dan C. Ain. (2016). Analisis C/N Rasio dan Total Bakteri pada Sedimen Kawasan Konservasi Mangrove Sempadan Sungai Betah Walang dan Sungai Jajar Demak. Prosiding Seminar Nasional Tahunan ke-V Hasil-Hasil Penelitian Perikana dan Kelautan. 519-530.

Putra, S. J. W., Nitisupardjo, M., \& Widyorini, N. (2014). Analisis Hubungan Bahan Organik dengan Total Bakteri pada Tambak Udang Intensif Sistem Semibioflok di Bbpbap Jepara. Diponegoro Journal of Maquares, 3(3):121-129.

Rahayu Kosasih, B., Samsuhadi, \& Indri Astuty, N. (2009). Kualitas Air Tanah di Kecamatan Tebet Jakarta Selatan Ditinjau dari Pola Sebaran Escherichia coli. Jurnal Ilmiah.

Rizqiana C, B. S. dan A. D. (2017). Hubungan Antara Kandungan Nitrat dan Fosfat dengan Kelimpahan Fitoplankton di Perairan Pulau Pari, Kepulauan Seribu. Jurnal Of Marques, 6(1), 43-50.

Sa'diyah, H., Afiati, N., \& Purnomo, P. W. (2018). Kandungan Bahan Organik Sedimen dan Kadar H2s Air di Dalam dan di Luar Tegakan Mangrove Desa Bedono, Kabupaten Demak. Journal of Maquares, 7(1), 78-85.

Sugiyono. (2012). Metode Penelitian Kuantitatif, Kualitatif dan R \& D.Bandung:Alfabeta. Metode Penelitian Kuantitatif, Kualitatif Dan R \& D.Bandung:Alfabeta.

Supriharyono. (2009). Peran Konservasi Keanekaragaman Hayati Dalam Menunjang Pembangunan Yang Berkelanjutan. Prosiding Seminar Nasional Penelitian, Pendidikan Dan Penerapan MIPA. Fakultas MIPA, Universitas Negeri Yogyakarta, 16 Mei 2009.

Tyas, D.E., N. Widyorini., dan A. S. (2018). Perbedaan Jumlah Bakteri dalam Sedimen pada Kawasan Bermangrove dan Tidak Bermangrove di Perairan Desa Bedono, Demak. Diponegoro Journal of Maquares, 7(2), 189-196.

Yulma, Y., Ihsan, B., Sunarti, S., Malasari, E., Wahyuni, N., \& Mursyban, M. (2017). Identifikasi Bakteri Pada Serasah Daun Mangrove yang Terdekomposisi di Kawasan Konservasi Mangrove dan Bekantan (KKMB) Kota Tarakan. Journal of Tropical Biodiversity and Biotechnology, 2(1), 28-33.

Zainuri, A. M., Takwanto, A., \& Syarifuddin, A. (2017). Konservasi Ekologi Hutan Mangrove Di Kecamatan Mayangan Kota Probolinggo Ach. Muhib Zainuri 1, Anang Takwanto 2, Amir Syarifuddin 3. 14, 1-7.

Zulkifli, H., Hanafiah, Z., \& Puspitawati, A. (2011). Struktur dan fungsi komunitas makrozoobenthos di perairan sungai Musi kota Palembang: telaah indikator pencemaran air. Prosiding Seminar Nasional Biologi. 